\title{
Isolation and Determination of Cellulose Degrading Bacteria Residing in Mandeep-khol Cave of Rajnandgaon, Chhattisgarh, India
}

\author{
ArunimaSur \\ Amity Institute of Biotechnology, Amity University Chhattisgarh, \\ Raipur \\ Study Area: Rajnandgaon, (Gandai), C.G., India \\ Coordinates: $\mathrm{N}_{21}{ }^{\circ} 39^{\prime}: \mathrm{E} 80^{\circ}{ }^{\circ} 8^{\prime}$
}

Keywords: Geomicrobiology, Cave bacteria,CMC Media, Mandhip Khol

\section{Introduction:}

Breaking of organic matters and recycling of organic wastes is a natural phenomenon in biodegradation. This can be used for waste management and environmental remediation, which is also known as bioremediation. It uses microorganisms, green plants and their enzymes which helps to bring the polluted environment back to its original condition. It is known that certain species of bacteria are potent in process of degradation.In nature plants holds major position over the earth for holding almost $80-90 \%$ carbon of the atmosphere. Degradation of which is required from complex to simple monomer for further utilization by other organisms. It will in turn help in recycling of organic elements. Cellulose is one of the main elements of the biomass energy (Scott). The chemical action of D- glucose molecules associated in $ß 1,4$ position results in formation of cellulose. There occurs hydrogen bonding within chains which results in formation of microf ibrils which is about 2-3nm in diameter.It's clear that a huge portion of plant life especially foliage and herbage in soil is cellulose and so degradation of cellulose is important in biogeochemical cycle of carbon, (Lederberg, 1992). It is estimated that around 40 billion ton of cellulose is generated every year. It has been observed that in recycling of carbon cellulolytic microorganisms acts as important part in recycling cellulose, (Beguin \& Anbert, 1993). Cellulases are also required in large quantities because of their application in many industries, such as textile, detergent, food, animal feed, bio-fuel, paper and pulp, pharmaceutical, and waste management (Bhat, 2000; Camassola \& Dillon, 2007; Gusakov, 2000). Moreover, it will

\section{Abstract}

Cellulose degrading-enzymes helps in achieving immense benefits of biomass utilization. It has been perceived that some species of bacteria has been proved as important microflora in degrading cellulose. The objective of this study was to explore cellulose degrading bacteria in mesophilic condition. The bacterial isolates were isolated from Mandeep-khol cave of Central India. In present studies a total of 32 isolates were isolated out of which Brevundimonas diminuta, Bacillus thuringiensis, Bacillus cereus and yellowish rough colony were found to grow best in CMC media and showed highest dry weight. The aim of the paper is to use explore those cellulose degrading bacteria for waste management.

help to promote organic farming as the practice of using chemical fertilizers is going down. As we know for promoting organic farming, vast amount of manure is required. So, to cope up with demand it is necessary to degrade and decompose plant and animal wastes which is mediated majorly by fungi and bacteria. This further will help to manage waste also. Researchers of this paper aimed to explore mesophilic bacteria capable of degrading cellulose from the cave. Cave provides a favorable condition for many cave-dwelling animals and plants. Apart from this variety of microorganisms are also which helps to degrade death and decay material present inside a cave and so helps to recycle the food chain, (Biswas, 2010; Karkun et al., 2012; Biswas et al., 2017; Biswas \& Biswas, 2017). It represents varied habitats in which bacteria contribute as one of the main in cave biodiversity. Bacteria and fungi are having potential in degrading organic materials like cellulose, pectin, lignin, etc. (Arunima pectin). Mostly it has been noticed that degradation occurs best when the temperature is high that is in thermophilic conditions, whereas in an environment like mesophilic where the temperature lies below $30^{\circ} \mathrm{C}$ the rate of degradation occurs at a slow pace. Thus we selected Mandeep-khol cave where the temperature remains almost constant throughout theyear .

The selected Mandeepkhol cave receives an enormous amount of plant parts like logs, twigs, dried leaves, etc. along with water streams which flow from nearby hillocks, (Karkun et al., 2014). The cave provides an appropriate niche for bats also. After a continuous survey and monitoring authors came with a fact that the bat guano, leaf litters are rapidly degraded inside a cave which gives the

*Corresponding Author: asur@rpr.amity.edu 
impression that microorganism residing inside cave must be potent degraders which degrades organic matters in temperature between $26-28^{\circ} \mathrm{C}$. so looking on to this we have selected bat guano, leaf litters, and logs / twigs as a sample.

The aim of this work is to the screen mesophilic cellulolytic Bacteria from the cave and to assay for their cellulose degradation potency. The samples were collected from Guano deposits, leaf litter, log, and twig deposits.

\section{Materials and methods:}

Sedimentray samples from Mandeep-khol cave were collected in sterile bags from different sources (Bat guano, logs and twigs, and leaf litters). Nutrient agar medium was used to isolate bacteria. The serial dilution method was adopted for the isolation of bacteria from samples. The Petri plates were kept for incubation at $28^{\circ} \mathrm{C}$. Bacteria isolated were then purely cultured to get axenic culture. The axenic bacterial culture was then kept in Carboxy methylcellulose media as a sole carbon source for testing their growth and was examined for cellulase activity, (Karkun et al., 2013). Colonial dry weight method was used to ascertain the bacterial growth.

Culture media: the culture medium contained $10 \mathrm{gm}$ Carboxymethylcellulose $(\mathrm{CMC})$, $1 \mathrm{~g} \mathrm{KHPO}_{4}, 0.5 \mathrm{~g} \mathrm{MgSO}_{4}$, o.5 $\mathrm{g} \mathrm{NaCl}$, o.o1g feSo4.7 $\mathrm{H}_{2} \mathrm{O}$, o.o1g $\mathrm{MnSO}_{4} \cdot \mathrm{H}_{2} \mathrm{O}$, o.3g $\mathrm{NH}_{4} \mathrm{NO}_{3}$, $12 \mathrm{~g}$ Agar per litre. About $20 \mathrm{ml}$ of prepared media was then poured in sterile Petri plates and isolated bacteria were inoculated to test their cellulase activity. It was then allowed to grow in $28^{\circ} \mathrm{C}$. The growth of colonies was measured at different intervals up to 5 days. Average of three replicates was considered for each organism. To measure mycelial dry weight isolates were grown in CMC broth with $\mathrm{CMC}$ as sole carbon source.

\section{Results and Discussion:}

From various sediments a total of 32 species were isolated. As earlier, maximum diversity was found from Bat guano followed by leaf litter and log and twig deposits (Karkun et al., 2014). From total isolated species of bacteria, 10 species grown well on media containing CMC as sole carbon source, thus giving the impression that 10 species of bacteria are potent degraders. According to the result, Brevundimonas diminuta, Bacillus thuringiensis, Bacillus cereus, and yellowish rough colony were found to grow best in CMC media and showed the highest dry weight, (Table-1). Bacillus pasteurii and Bacillus cereus, Halobacillus, Aeromicrobium, and Brevibacterium were found to have the best cellulase activity. Wongwilaiwalin et al. (2010) has worked with eight major microbes for testing their lignocellulose degrading potential. The microorganisms were potent cellulose degraders whereas Kim et al. (2012) observed three strains of bacteria showing higher potential for cellulose degradation and identified them as Bacillus subtilis strains. Earlier, Vimal et al. (2016) has reported cellulose-degrading bacteria from industrial and agricultural areas. They even optimized cellulase production. Rawway et al. (2018) has screened cellulolytic bacteria from five different sources by using two different medium that was cellulose agar and carboxymethyl cellulose agar. They characterized ten bacterial isolates with high potential in cellulose degradation. In the present work CMC media was used. Islam \& Roy (2018) have screened and identified cellulase from cellulose producing bacteria from molasses. They chose sugar industry waste with the motive of using waste for some good yield. Mondejar et al. (2016) worked on forest soil microorganisms where they found their potentiality in degrading of cellulose and hemicellulose. They used CMC as a sole carbon source. They have isolated 115 different bacterial species in which best three degraders were chosen for genomic study. In the present study, attempt has been taken to find the best degraders at molecular level. Hussain et al. (2017) isolated cellulose degrading bacteria from soil and ward poultry of Egyptian environment. They optimized and identified cellulolytic bacteria. Similar work was done by Bassil et al. (2015) where they isolated cellulose degrading bacteria from waste. This work also claims that these bacteria can be used for managing waste as organic waste can be easily degraded by this.

Table- 1: Colonial growth (CG) and Colonial Dry Weight (CDW) in cellulose media

\begin{tabular}{llll}
\hline Isolated Bacteria & CG & CDW/ 5oml & CDW/ 1000ml \\
\hline Bacillus cereus & ++ & $0.08 \mathrm{gm}$ & $0.16 \mathrm{gm}$ \\
Bacillus thuringiensis & ++ & $0.07 \mathrm{gm}$ & $0.14 \mathrm{gm}$ \\
Brevundimonas diminuta & ++ & $0.09 \mathrm{gm}$ & $0.18 \mathrm{gm}$ \\
Cream colony I & + & $0.02 \mathrm{gm}$ & $0.04 \mathrm{gm}$ \\
Cream rough colony II & + & $0.04 \mathrm{gm}$ & $0.08 \mathrm{gm}$ \\
Cream rough colony III & + & $0.035 \mathrm{gm}$ & $0.07 \mathrm{gm}$ \\
Creamish yellow colony I & + & $0.04 \mathrm{gm}$ & $0.08 \mathrm{gm}$ \\
Lemon yellow colony II & + & $0.028 \mathrm{gm}$ & $0.56 \mathrm{gm}$ \\
Transparent colony II & + & $0.03 \mathrm{gm}$ & $0.06 \mathrm{gm}$ \\
Yellowish rough colony & ++ & $0.02 \mathrm{gm}$ & $0.04 \mathrm{gm}$ \\
\hline
\end{tabular}

$+=$ poor,$++=$ moderate,$+++=$ good,$++++=$ excellent

Finally, the microorganisms present in cave are quite potent in degrading animal and plant products which contains cellulose, lignin and other organic material in good amount. So these microbes can further be utilized as decomposition of organic wastes so as to promote organic farming and proper recycling of elements back to environment.

\section{References:}

Bassil, N.M., Bewsher, A.D., Thompson, O.R. \& Llyod, J.R. (2015): Microbial degradation of cellulosic material under intermediate-level waste simulated conditions. Mineralog. Mag., 79(6);:1433-1441.

Beguin, P. \& Anbert J.P. (1994): The biological degradation of cellulose. FEMS Microbiol. Rev., 13(1):25-58

Bhat, M.K. (2000): Cellulases and related enzymes in biotechnology. Biotechnol. Adv., 18:355-383. 
Biswas, J. (2010): Kotumsar Cave biodiversity: a review of cavernicoles and their troglobiotic traits. Biodivers. Conserv. 19: 275 .

Biswas, D. \& Biswas, J. (2018): Microhabitat dependant the Proliferation of microfungi in Dandak cave of Kanger Valley National Park, India. Ambient Sci., 6 (1):26-30.

Biswas, D., Biswas, J. \& Sharma, D. (2017): Habitat and Season Dependent the Invasion of Micro-fungi in Decaying Wooden Flinders: a Case Study of the Dandak Cave of Chhattisgarh, India. Ambient Sci., 04(2):22-26.

Biswas, D. \& Biswas, J. (2018): Major Deteriorative, Pathogenic and Benef icial Fungi Reported from Various Subterranean Caves of the World: A Mini Review.Int.J. Ecosys., 7(1):11-16.

Camassola, M. \& Dillon, A.J.P. (2007): Production of cellulases and hemicellulases by Penicillium echinulatum grown on pretreated sugar cane bagasse and wheat bran in solid-state fermentation. L. Appl. Microbiol., 103: 2196-2204.

Gupta, P., Samant, K. \& Sahu, A. (2012): Isolation of cellulosedegrading bacteria and determination of their cellulolytic potential. Int. J. Microbiol., 6:1-5.

Gusakov, A.V., Berlin, A.G., Popova, N.N., Okunev, O.N., Sinitsyn, A.O. \& Sinitsyn, A.P. (200o): A comparative study of different cellulose preparations in the enzymatic treatment of cotton fabrics. Appl. Biochem. Biotechnol., 88;:119-126.

Hussain, A.A., Abdel-Salam, M.S., Abo-Ghalia, H.H., Hegazy, W. K. \& Hafez, S.S. (2017): Optimization and molecular identification of novel cellulose degrading bacteria isolated from Egyptian environment. J. Gen. Eng. Biotechnol., 15; 7785.

Islam, F. \& Roy, N. (2018): Screening, purification and characterization of cellulase from cellulase producing bacteria in molasses. BMC Res. Notes. 11:445.
Karkun, A., Tiwari, K.L. \& Jadhav, S.K. (2013): Some mesophilic cellulolytic fungi from Mandeepkhol cave, Durg (CG). Flora Fauna. 19(2):263-266.

Karkun, A., Tiwari, K.L. \& Jadav, S.K. (2012): Fungal Diversity of Mandeepkhol Cave in Chhattisgarh, India. Adv. Biores., 3(2): 119-123.

Karkun, A., Jadhav, S.K. \& Tiwari, K.L. (2013): Lignin degradation by cave dwelling fungi. Int. J. Pharmacol. Biol. Sci., 7(2): 81-86.

Karkun, A., Patle, K. \& Verma, S. (2014): Bacterial diversity of Mandeepkhol cave, Rajnandgaon district of C.G., India. Int. I. Inn. Sci. Eng. Technol., 1(4):491-499.

Karkun, A., Verma, S. \& Patle, K. (2014): Study of Pectinolytic Bacteria residing in Mandeepkhol cave, Rajnandgaon district of CG India. Int. J. Curr. Microbiol. App.Sci.3(8):547-552.

Kyoung, K.Y., Shin-Chan, L., Young-You, C., Jeong-Hyun, O. \& Hwan-Young, K. (2012): Isolation of cellulolytic Bacillus subtilis strains from agricultural environments. ISRN Microbiol., 10.

Lederberg, J. (1992): Cellulases. In: Encyclopedia of Microbiology (vol.1; A-C). Pub. by: Academic Press.

Mondéjar, R.L., Zühlke, D., Becher, D., Riedel, K. \& Baldrian, P. (2016): Cellulose and hemicelluloses decomposition by forest soil bacteria proceeds by the action of structurally variable enzymatic systems. Sci. Reports., 6, 25279.

Rawway, M., Ali, G.S. \& Badawy, S.A. (2018): Isolation and identif ication of cellulose degrading bacteria from different sources at Assiut Governorate (Upper Egypt).J. Ecol. Health Environ., 6(1):15-24.

Vimal, J., Venu, A. \& Joseph, J. (2016): Isolation and identification of cellulose degrading bacteria and optimization of the cellulase production. Int. J. Res. Biosci., 5(3):58-67. 